\title{
The impact of large scale biomass production on ozone air pollution in Europe
}

\author{
Joost B. Beltman ${ }^{\mathrm{a}}$, Carlijn Hendriks ${ }^{\mathrm{a}}$, Markus Tum ${ }^{\mathrm{b}}$, Martijn Schaap ${ }^{\mathrm{a}, *}$ \\ ${ }^{a}$ TNO, Department of Climate, Air and Sustainability, P.O. Box 80015, 3508 TA Utrecht, The Netherlands \\ ${ }^{\mathrm{b}}$ German Aerospace Center (DLR), German Remote Sensing Data Center (DFD), Oberpfaffenhofen, 82234 Weßling, Germany
}

\section{H I G H L I G H T S}

- Future poplar biomass plantations may significantly impact ozone levels in Europe.

- Growing poplar on $5 \%$ of European farmland enhances isoprene emissions by $45 \%$.

- Ozone indicators for human health and vegetation increase by up to $25 \%$ and $40 \%$.

- Air pollution mitigation strategies should consider land use management.

\section{A R T I C L E I N F O}

\section{Article history:}

Received 28 March 2012

Received in revised form

11 January 2013

Accepted 8 February 2013

\section{Keywords:}

Ozone

Biomass plantations

Chemical transport model

Isoprene emissions

Poplar

\begin{abstract}
A B S T R A C T
Tropospheric ozone contributes to the removal of air pollutants from the atmosphere but is itself a pollutant that is harmful to human health and vegetation. Biogenic isoprene emissions are important ozone precursors, and therefore future changes in land use that change isoprene emissions are likely to affect atmospheric ozone concentrations. Here, we use the chemical transport model LOTOS-EUROS (dedicated to the regional modeling of trace gases in Europe) to study a scenario in which $5 \%$ of the crop- and grass-land in Europe is converted into poplar plantations to be used for biofuel production. Although this scenario is rather conservative, our simulations project that isoprene emissions are substantially increased by an average of $45 \%$ over the simulated domain. As a consequence, ozone peak values are expected to increase by up to $6 \%$, and ozone indicators for damage to human health and vegetation by up to $25 \%$ and $40 \%$, respectively. Finally, we show that after the change in land use $\mathrm{NO}_{x}$ emission reductions of $15-20 \%$ in Europe would be required to restore the ozone levels to current values. Because biomass production is expected to increase throughout Europe in the coming decades, we conclude that careful consideration of the tree types and regions to be used is required to constrain the concomitant air pollution to a minimum.
\end{abstract}

(c) 2013 Elsevier Ltd. All rights reserved.

\section{Introduction}

Ozone is a natural compound of the troposphere that has an important role in the cleansing capacity of the atmosphere. During the past centuries ozone levels have increased as a result of human activities such as transportation, industrial processing and energy production. Photochemical processes influenced by anthropogenic emissions of nitrogen oxides $\left(\mathrm{NO}_{x}\right)$ and Volatile Organic Compounds (VOCs) cause current tropospheric ozone levels to be substantially increased compared to its natural background (Dentener et al., 2005). Increased ozone concentrations, especially during

\footnotetext{
* Corresponding author. Tel.: +31 88 8662074; fax: +31 888662044 .

E-mail address: martijn.schaap@tno.nl (M. Schaap).
}

summer smog episodes, have a negative effect on humans, animals and vegetation (Royal Society, 2008). For example, exposure to high ozone concentrations may give rise to respiratory and possibly cardiovascular problems and is thought to lead to premature deaths (Bell et al., 2004). Furthermore, high ozone levels can be harmful to plant leaves, thus leading to economic damage due to decreased forest growth and decreased crop yields (Adams et al., 1982; Krupa et al., 1998). During the last three decades international emission control efforts have been undertaken to reduce the exposure of the population and vegetation to ozone in the US and Europe. Trend analyzes have shown that this strategy has successfully reduced ozone peak values (Royal Society, 2008).

Ozone production results from a complex interplay by nitrogen oxides and organic compounds from natural and anthropogenic sources. Variability in ozone concentrations is driven in part by 
biogenic emissions of VOCs, mainly in the form of isoprene (Curci et al., 2009). The rates of isoprene emission are largely dependent on plant species, and increase strongly with temperature and with photosynthetically active radiation intensity (Guenther et al., 1993; Guenther, 1995). Therefore, changes in isoprene emissions and ozone levels may result from potential future modifications in climate (due to global warming) as well as in land use (e.g., due to ongoing urbanization and de- or re-forestation). Indeed, climate impact studies consistently show that ozone levels are expected to increase at constant anthropogenic emissions, predominantly because of increased biogenic VOC emissions at higher ambient temperatures (Jacob and Winner, 2009). Such temperature-driven increases in biogenic emissions may either be counteracted or exacerbated by land use changes (e.g., Sanderson et al., 2003; Wiedinmyer et al., 2006; Chen et al., 2009; Ganzeveld et al., 2010). This depends on the considered type of land use modification like urbanization, cropland expansion, tree planting, or natural vegetation distribution differences associated with global warming. Thus, the impact of land use changes on air pollution can be substantial when it is combined with climate change. However, the effect of land use changes alone, i.e., without a concomitant climate change has received little attention so far, especially with respect to the European continent (for exceptions see below).

One reason for a future land use shift is a potential large-scale transition toward the usage of biomass as a renewable energy source. For Germany, the current annual share of renewables amongst all energy sources is $10.9 \%(\sim 1 \mathrm{EJ})$, most of which $(\sim 0.7$ EJ) is biomass-based (BMU, 2012). Germany has agreed to increase the percentage of energy from renewables to $18 \%$ by 2020 , a plan that can be seen as challenging. Globally, $16.6 \%$ of energy came from renewable sources in 2008 , and the majority (75\%) of this was biomass-based. The recent domination of biomass-based sources amongst renewables is largely due to the increased production of liquid fuels such as bio-diesel (BMU, 2012). Because this trend is expected to continue in the future, large regions of crop- and grassland will be needed to supply the required biomass. Fischer et al. (2010) calculated that within Europe $15-30 \%$ of the current grass- and crop-land could be available for biomass production by 2030 , without impinging on requirements for self-sustainability in terms of food and feed production. However, in some countries a policy change may be required for such large-scale transitions. For example, in Germany it is currently not allowed to modify grassland into biomass plantations. Nevertheless, in such a scenario of large scale biomass production, this could in the future annually generate up to 5 EJ (Fischer et al., 2010; Thrän et al., 2011), i.e., one third of the total energy demand of the transport sector in the European Union. In conclusion, the landmass available for biomass-based sources in Europe as well as its ensuing energy potential is substantial.

Bio-energy based plantations that run on woody biomass need an ongoing supply of chipped wood, and therefore fast-growing tree species are required to provide such a constant flow of material. Candidate species for biomass plantations in Europe are therefore tree species such as poplar, willow, and eucalyptus. The isoprene emission potentials of these species are relatively high when compared to most other common tree species in Europe such as beech, fir, and pine species (Table 1 ; note that oaks are an exception). Thus, additional biogenic emissions as a consequence of large-scale biomass production are likely to affect ozone levels.

The potential effect of large-scale biomass plantations on isoprene emissions and consequent ozone air pollution has been investigated in a limited number of studies, mainly by applying chemical transport models (CTMs) to different parts of the earth (Lathière et al., 2006; Wiedinmyer et al., 2006; Hewitt et al., 2009; Ashworth et al., 2011; Pyle et al., 2011). With respect to Europe, two
Table 1

Overview of the biomass density (in $\mathrm{g} \mathrm{m}^{-2}$ ) and isoprene emission coefficient (in $\mu \mathrm{g}$ per gram dry mass per hour) for selected vegetation types and tree species (based on Simpson et al., 1999; Karl et al., 2009). Tree species that are frequently used for biomass production are highlighted.

\begin{tabular}{lccl}
\hline Name & $\begin{array}{l}\text { Biomass } \\
\left(\mathrm{g} \mathrm{m}^{-2}\right)\end{array}$ & $\begin{array}{l}\text { Isoprene coefficient } \\
\left(\mu \mathrm{g} \mathrm{g} \mathrm{DM} \mathrm{h}^{-1}\right)\end{array}$ & Reference \\
\hline Arable land & 1067.5 & 0.5 & Karl $^{\mathrm{a}}$ \\
Permanent crops & 251 & 0.5 & Karl $^{\mathrm{b}}$ \\
Grassland & 400 & 0.1 & Simpson $^{\mathrm{C}}$ \\
Deciduous forest & 300 & 10 & Simpson $^{\mathrm{c}}$ \\
Abies alba & 1400 & 0.1 & Simpson \\
Acer sp. & 320 & 0.1 & Simpson \\
Betula pubescens & 320 & 0.1 & Simpson \\
Eucalyptus sp. & 400 & 20 & Simpson \\
Fagus sylvatica & 320 & 0.1 & Simpson \\
Populus alba & 320 & 60 & Simpson \\
Pinus pinea & 700 & 0.1 & Simpson \\
Prunus avium & 300 & 0.1 & Simpson \\
Quercus robur & 320 & 60 & Simpson \\
Salix sp. & 150 & 34 & Simpson \\
Ulmus minor & 320 & 0.1 & Simpson \\
\hline
\end{tabular}

a Values for arable land are calculated as the average of 'common wheat' and 'other cereals' from Karl et al. (2009), where emissions are considered to occur only from early May until early September.

b Values for permanent crops are taken as 'fruit tree and berry plantations' from Karl et al. (2009).

c Values for deciduous forest without a tree type assigned are taken as being a composite of various common tree types over Europe.

studies were performed: First, Lathière et al. (2006) investigated the potential consequences of biomass plantations on biogenic emissions at a $1^{\circ}$ by $1^{\circ}$ resolution. Second, Ashworth et al. (2011) looked at their impact on both biogenic emissions and on ozone air pollution at a $1.9^{\circ}$ by $1.3^{\circ}$ resolution. Except for these coarsescaled studies, the potential impact of large-scale biomass production on ozone levels in Europe has not been investigated. Comparison of global model results to ground-level observations suggests that resolutions of $1 \times 1$ degree or lower are too coarse to resolve regional ozone production (Wild and Prather, 2006). Indeed, evaluations of global and regional CTMs show that regional models typically perform better (Van Loon et al., 2007; Emery et al., 2012). A likely explanation for this is that ozone chemistry is fast (of the order of minutes-hours): with a high-resolution model the different chemical regimes that are induced by emission patterns of biogenic and anthropogenic sources can be separated, which leads to a proper description of regional ozone formation.

Here, we provide a dedicated regional modeling approach (at $0.5^{\circ}$ by $0.25^{\circ}$ resolution) to investigate this topic by employing the CTM LOTOS-EUROS, which is especially tailored to the modeling of trace gases and particulate matter in Europe. We study a conservative future scenario in which only $5 \%$ of the crop- and grass-land in Europe is considered to be converted into poplar plantations. We show that the effect of the isoprene emissions is primarily on the daily ozone peaks, and for the first time explore the impact on ozone indicators for human health (SOMO35) and for vegetation damage (AOT40f). Finally, we assess the $\mathrm{NO}_{x}$ emissions reduction that would be required to restore the ozone levels to normal values, thus putting the ozone air pollution due to new poplar plantations in perspective.

\section{Methods}

\subsection{LOTOS-EUROS model}

In order to study the impact of poplar plantations on ozone distributions over Europe, we used LOTOS-EUROS version 1.8.2, which is a three-dimensional CTM that simulates air pollution in 
the lower troposphere. Previous versions of LOTOS-EUROS have been used for the assessment of air pollution (e.g., Schaap et al., 2004a, 2004b; Barbu et al., 2009; Manders et al., 2009, 2010). LOTOS-EUROS is used to make operational forecasts of ozone, nitrogen dioxide and particulate matter within the MACC (Monitoring Atmospheric Composition and Climate; EU FP7 project) ensemble (Curier et al., 2012). Furthermore, LOTOS-EUROS has frequently participated in international model comparisons concerning ozone (Hass et al., 2003; Van Loon et al., 2007; Solazzo et al., 2012), particulate matter (Cuvelier et al., 2007; Stern et al., 2008) and source-receptor matrices (Thunis et al., 2007). For a detailed model description we refer to elsewhere (Schaap et al., 2009); here we provide a brief description focusing mainly on the most relevant aspects for the current study.

The projection used in our simulations is longitude-latitude at a grid resolution of $0.50^{\circ}$ longitude $\times 0.25^{\circ}$ latitude (in Europe approximately $25 \times 25 \mathrm{~km}$ ). The simulated domain is a rectangular grid from $15^{\circ} \mathrm{W}$ to $35^{\circ} \mathrm{E}$ and $35^{\circ} \mathrm{N}$ to $70^{\circ} \mathrm{N}$, which encompasses Europe (Fig. 1a). For the boundary conditions we employ the Global and regional Earth-system (Atmosphere) Monitoring using Satellite and in-situ data (GEMS) re-analysis and forecasts (Hollingsworth et al., 2008). This is based on a coupling of the European Centre for Medium-range Weather Forecasts (ECMWF) model (Flemming et al., 2009) to the CTM Model for Ozone and Related chemical Tracers (MOZART; Emmons et al., 2010). In the vertical direction the model extends from 0 to $3.5 \mathrm{~km}$ above sea level, and consists of three dynamical layers to describe differences in diffusive behavior at various heights. The lowest layer is the mixing layer in which most emissions take place and whose height varies over time and space due to daily changes in air temperature. The mixing layer height is extracted from meteorological input data originating from the ECMWF model (Flemming et al., 2009), which are used to drive LOTOS-EUROS. On top of the mixing layer we consider two reservoir layers. The height of these reservoir layers together is set to the difference between the ceiling $(3.5 \mathrm{~km})$ and the mixing layer height. The individual reservoir layers are equally thick with a minimum of $50 \mathrm{~m}$. Occasionally, the mixing layer extends near or above $3.5 \mathrm{~km}$, which means that the ceiling exceeds $3.5 \mathrm{~km}$ in those cases. Apart from the mixing and reservoir layers, a surface layer with a fixed depth of $25 \mathrm{~m}$ is included to monitor ground-level concentrations.

Advection in all directions is handled by applying the monotonic advection scheme developed by Walcek (2000). The number of time steps within the routine is dependent on the courant number. (a)

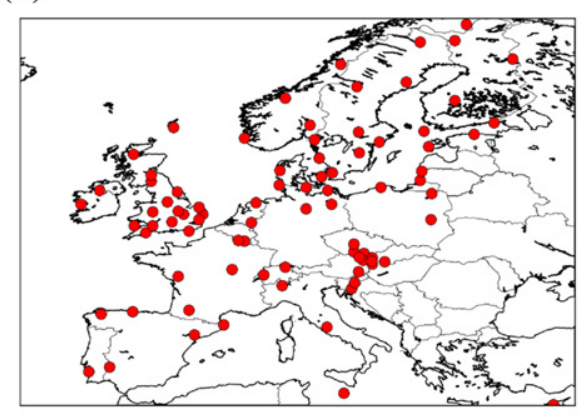

(b)

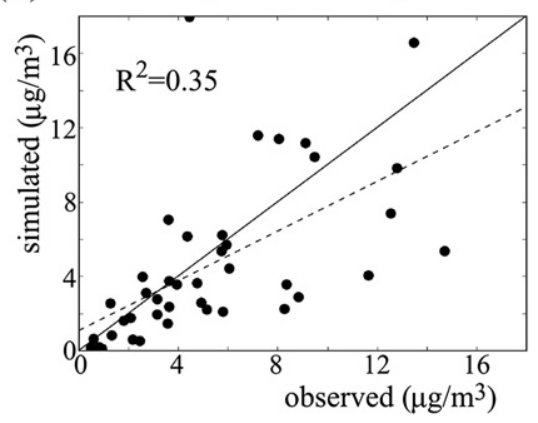

(c)

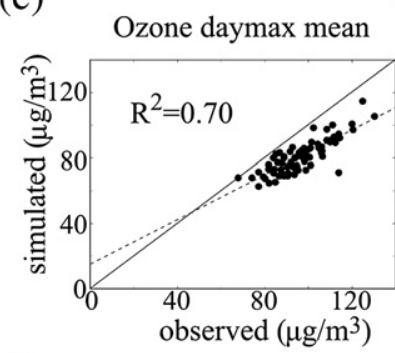

(d)

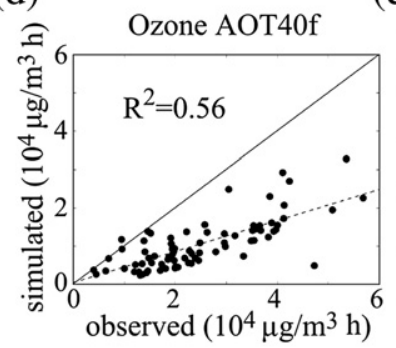

(e)

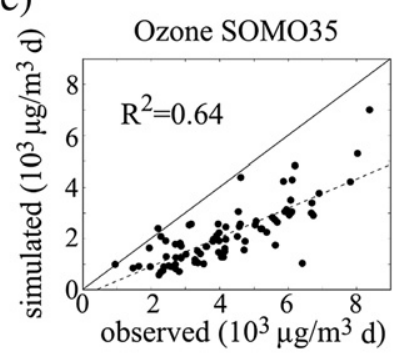

(f)

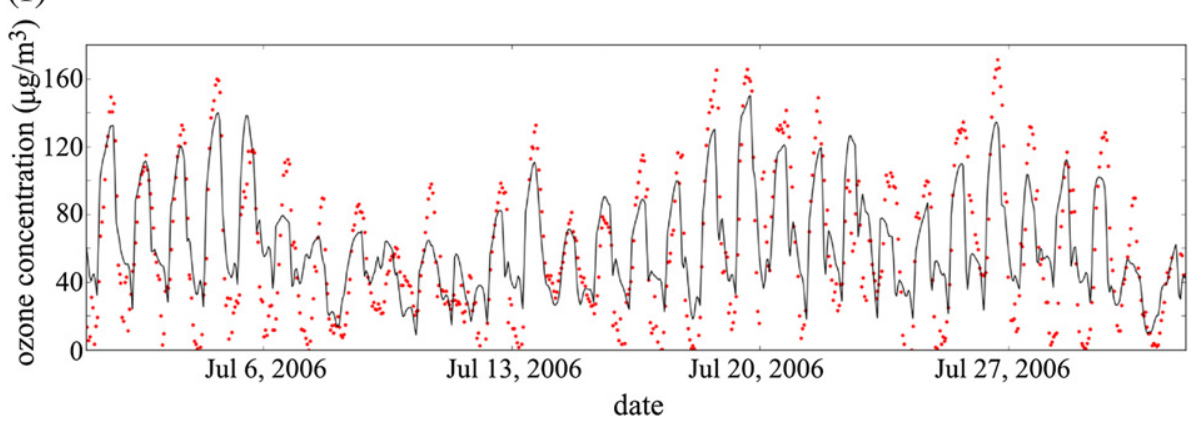

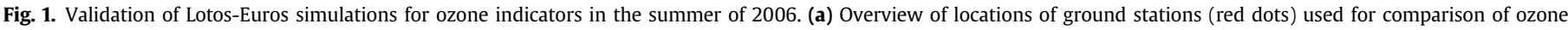

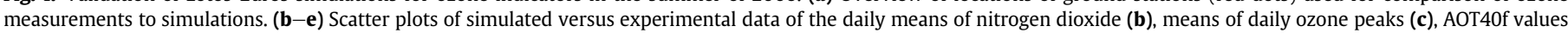

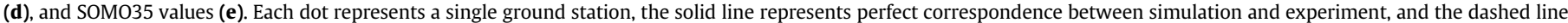

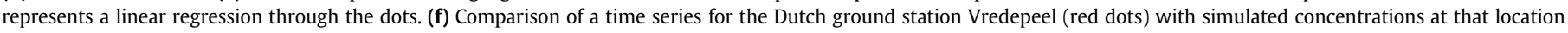
(solid line). (For interpretation of the references to color in this figure legend, the reader is referred to the web version of this article.) 
Gas phase chemistry is described using the TNO CBM-IV scheme, which is a condensed version of the original scheme by Whitten et al. (1980). Isoprene chemistry and hydrolysis of $\mathrm{N}_{2} \mathrm{O}_{5}$ are described following Adelman (1999) and Schaap et al. (2004a), respectively. Dry deposition in LOTOS-EUROS is parameterized according to the well-known resistance approach following the EDACS system (Erisman et al., 1994; Van Zanten et al., 2010). The stomatal resistance is described by the parameterization of Emberson et al. (2000a,b), and the aerodynamic resistance is calculated for all land use types separately. Wet deposition of trace gases and aerosols are treated using simple scavenging coefficients (Schaap et al., 2004a).

For anthropogenic trace gas emissions we incorporate the widely used TNO-MACC emission database for 2005 (Denier van der Gon et al., 2010; Kuenen et al., 2011). The temporal variation of the emissions is represented by time factors (Builtjes et al., 2003). Specifically, for each emission source category the annual total emission is multiplied by factors for (i) the month of the year, (ii) the day of the week, and (iii) the hour of the day.

Biogenic VOC emissions are derived using detailed information on tree types in Europe because the biogenic emission factors are extremely variable between species (e.g., see Table 1). Therefore, the land use dataset (Steinbrecher et al., 2009) was combined with the distributions of 115 tree species over Europe (Koeble and Seufert, 2001). These tree species are allocated to all forested areas of the land use dataset at a resolution of about $2 \mathrm{~km} \times 1 \mathrm{~km}$ ), and the resulting database is aggregated to the required resolution during model initialization (Schaap et al., 2009). Due to the merging of two different databases, it regularly occurs that forest areas within a grid point cannot be completely filled up with specific tree species. For example, at a specific grid point the fraction of deciduous forest from the land use dataset could be 0.5 , whereas the sum of all deciduous tree species from the tree dataset could only amount to a fraction of 0.3 . The 'rest' fraction of deciduous forest (in the example a fraction of 0.2 ) then remains tagged with 'deciduous forest' rather than with specific tree species. During each simulation time step, biogenic isoprene and monoterpene emissions are calculated as a function of the biomass density and standard emission factor of the species or land use class (Table 1; for full table see Schaap et al., 2009). Moreover, the role of the local temperature and photo-synthetically active radiation are taken into account in the biogenic emissions by following the empirically designed algorithms proposed by Guenther et al. (1993) and Tingey et al. (1980). Our implementation of biogenic VOC emissions is similar to the approach by Steinbrecher et al. (2009).

\subsection{Scenario definition and analysis}

In our scenario we consider $5 \%$ of the European crop- and grassland to be converted into poplar plantations, which represents a conservative change relative to the amount of available land for biomass production in the future (Fischer et al., 2010). To implement this scenario, during the initialization of the tree database and the land use database, for each grid point the fraction assigned to the tree species Populus alba is increased by $5 \%$ of the land fraction used for crop- and grass-land (which is decreased by that same amount). The same increase is assigned to the land use class for deciduous forest, such that the amount of forest that cannot be assigned to tree species remains the same after the land use modification. For the entire simulated domain, the total land area changed amounts to $18.3 \mathrm{MHa}$. Note that the new poplar plantations modify the biogenic VOC emissions as well as the deposition per grid point.

The simulations are carried out for the summer smog season (Apr 1st-Oct 1st) of 2006, which had a few warm episodes during summertime in western Europe. We compare the baseline case and the main scenario to quantify the impact of new poplar plantations. To put the results into perspective we also perform simulations with up to $50 \%$ reductions in $\mathrm{NO}_{x}$ emissions (in addition to the changes caused by the new poplar plantations). Three ozone indicators are used to assess the effect of our scenarios on ozone levels. First, the daily maximum in ozone concentration, which usually occurs during late afternoon. Second, the AOT40f (in $\mu \mathrm{g} \mathrm{m}^{-3}$ $\mathrm{h}$ ), which is an indicator for vegetation protection, and is defined as the sum of the differences between hourly concentrations greater than $80 \mu \mathrm{g} \mathrm{m}^{-3}$ and $80 \mu \mathrm{g} \mathrm{m}^{-3}$ over the period April-September. In this calculation, only the values measured between 8.00 and 20.00 Central European Time are included. The third ozone indicator is the SOMO35 (in $\mu \mathrm{g} \mathrm{m}^{-3} \mathrm{~d}$ ), which is the sum of means over $35 \mathrm{ppb}$ $\left(70 \mu \mathrm{g} \mathrm{m}^{-3}\right)$, and is typically used as an indicator for human health damage. It is defined as the sum of the differences between daily maxima of 8-h running means exceeding $35 \mathrm{ppb}$ and $35 \mathrm{ppb}$ over a certain period. Note that these measures are frequently used yet come with disadvantages. For example, a well-known disadvantage of the AOT40f approach is that it doesn't take into account that vegetation damage depends on factors other than just ground-level ozone concentrations (Royal Society, 2008). Meteorological and environmental parameters such as air humidity and water deficit are important determinants for the ozone flux into plants, because leaf stomata may be closed in dry conditions. Therefore, the gradient of projected vegetation damage from North- to SouthEurope is less for a flux-based than for an AOT40f approach (Simpson et al., 2007).

\subsection{Model evaluation procedure}

To verify the relation between simulated and experimentally determined ozone and nitrogen dioxide concentrations across Europe we use measured concentrations of trace gases for 2006 from the European Monitoring and Evaluation Programme (EMEP) monitoring network (Hjellbrekke and Fjæraa, 2009; www.emep. int). We use only background stations situated in rural areas. Furthermore, mountain stations (above $700 \mathrm{~m}$ ) and stations with a 2006 summer data coverage of less than 75\% (determined separately for ozone and nitrogen dioxide) are excluded from the procedure. As a result, in the statistical comparison between projected and observed values, up to 83 stations were used for the ozone indicators and 41 for nitrogen dioxide. Statistical parameters investigated include averages, percentage coverage, bias, RMSE, and temporal correlation (Table 2). For each of these statistics, values are first calculated for each station separately, and the average per station is presented.

Table 2

Comparison of experimental observations at ground stations and simulated data.

\begin{tabular}{|c|c|c|c|c|}
\hline & $\begin{array}{l}\text { Ozone } \\
\text { daily peak } \\
\text { concentration } \\
\left(\mu \mathrm{g} \mathrm{m}^{-3}\right)\end{array}$ & 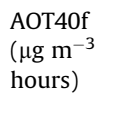 & 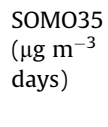 & $\begin{array}{l}\text { Nitrogen dioxide } \\
\text { concentration } \\
\left(\mu \mathrm{g} \mathrm{m}^{-3}\right)\end{array}$ \\
\hline Observed mean & 97.8 & 24892.6 & 4257.3 & 5.4 \\
\hline Simulated mean & 81.6 & 10499.1 & 2183.7 & 4.7 \\
\hline $\begin{array}{l}\text { Number of ground } \\
\text { stations }\end{array}$ & 83 & $78^{a}$ & 83 & 41 \\
\hline Mean data coverage & $98.5 \%$ & n.a. & n.a. & $94.0 \%$ \\
\hline Mean bias & -16.1 & -14393.5 & -2073.6 & -0.7 \\
\hline Mean RMSE & 24.6 & n.a. & n.a. & 3.7 \\
\hline $\begin{array}{l}\text { Mean temporal } \\
\text { correlation }^{\mathrm{b}}\end{array}$ & 0.69 & n.a. & n.a. & 0.37 \\
\hline
\end{tabular}

${ }^{a}$ Note that ground stations are excluded when their ozone data coverage is insufficient $(<90 \%)$ to calculate the AOT40f.

b For ozone, correlations are based on the maximal daily values, and for nitrogen dioxide they are based on daily means. 


\section{Results}

\subsection{Comparison of LOTOS-EUROS simulations with ground observations}

We start by investigating how well the LOTOS-EUROS CTM projects experimental measurements of trace gas concentrations at the surface. Because we focus on ozone air pollution, we compare our 2006 summer simulation results for ozone and an important precursor (nitrogen dioxide) to observations at ground stations (Fig. 1a). For nitrogen dioxide the simulated daily means typically slightly underestimate the observed values, and only at a few stations the simulations are further off (Fig. 1b; Table 2). The relatively low temporal correlation coefficient for this primary component is a common feature for European CTMs (Vautard et al., 2009). Regarding the ozone indicators studied (daily peak ozone values, AOT40f, and SOMO35), our simulations underestimate the experimental measurements (Fig. 1c-e; Table 2). Ozone peak values are underestimated by on average $17 \%$. Part of the underestimation is systematic and can be attributed to the boundary conditions, which are on the low side for ozone. However, the strongest underestimations occur at the high end of the concentration range. Overall, the spatial correlation for ozone daily maximum is quite good. Furthermore, the temporal correlations between the observed and simulated peak ozone values at a single location are on average high (Table 2, Fig. 1f), varying from a range of 0.75-0.85 in Central Europe to values of $0.5-0.7$ in Southern and Northern Europe. The lower model performance in southern Europe is a consequence of the more complex terrain and meteorological circumstances compared to central Europe. The European geographical variability in model performance is a typical feature in CTMs (Van Loon et al., 2007; Vautard et al., 2009). This analysis suggests that we correctly capture the most important processes determining the variability of the daily ozone peaks in space and time. The underestimation of the AOT40f and the SOMO35 values is more pronounced, which is caused by the concentration threshold in the determination of these indicators. However, the spatial correlation is only slightly lower than for ozone peak values. For a more elaborate evaluation of LOTOS-EUROS for ozone we refer to Curier et al. (2012).

The response to emission reductions for LOTOS-EUROS simulations has been compared to that of a number of other CTMs within EURODELTA (Thunis et al., 2010). With respect to reductions in nitrogen oxides the LOTOS-EUROS simulation results were consistent with the results of other models. However, responses to land use changes or changes in biogenic emissions were not addressed within EURODELTA. Nevertheless, because our model evaluation shows that our simulations are able to capture the variability in ozone between regions with different climatic conditions and, importantly, different pollution regimes $\left(\mathrm{NO}_{x} / \mathrm{VOC}\right.$ ratios), we conclude that the model is suited to study the effect of modifications in land use as well as $\mathrm{NO}_{x}$ emissions on ozone air pollution. However, it might be that the absolute impact on AOT40f and SOMO35 as presented in this paper are underestimated.

\subsection{Impact of new poplar plantations on isoprene emissions}

In our scenario we consider that $5 \%$ of the current crop- and grass-land is converted into fast-growing poplar plantations. In large parts of Europe agricultural land use is dominant, and the fraction of deciduous forest tends to be limited (Fig. 2a). Therefore, within each simulated grid point (varying in size from $\sim 500 \mathrm{~km}^{2}$ in the northern part of the domain to $\sim 1250 \mathrm{~km}^{2}$ in the southern part of the domain), tens of squared kilometers of land are replaced with forest in our scenario (Fig. 2b). For the Scandinavian countries, the changes are minor because of the limited agricultural activities in those countries.

In the isoprene emission distribution for the current land use both the forest distribution across Europe and a general south to north gradient is visible (Fig. 2c). This gradient is caused by different meteorological conditions and the dependency of isoprene emissions on temperature and radiation intensity. Fastgrowing tree species such as poplars tend to be high emitters of isoprene, whereas grasses and crops are low emitters (Table 1). Therefore, the calculated effect of new poplar plantations on isoprene emissions is substantial: For the entire simulated domain, isoprene emissions for the summer of 2006 increased by approximately $45 \%$ from a total of nearly $5 \mathrm{Tg}$ to more than $7 \mathrm{Tg}$. Examination of the relative increases across the domain shows that in dominant agricultural areas, such as the United Kingdom, Ireland, Denmark, northwestern France, northern Germany, the Po Valley and the Ukraine, increases of more than $100 \%$ are observed (Fig. 2d). For other regions, the importance of the change depends on the ratio between the change in forest cover due to the scenario and already existing forest cover. Mountainous regions can be clearly identified because relatively few land use changes occur (Fig. $2 \mathrm{~b}$ and d). Our conservative scenario leads to a doubling of isoprene emissions in countries with low forest cover such as the Netherlands and the UK (Fig. 2e). In an absolute sense, the largest increases are projected to occur in Southern Europe, as expected from the meteorological conditions.

\subsection{Impact of new poplar plantations on ozone indicators}

To investigate the impact of the additional isoprene emissions due to new poplar plantations on ozone air pollution, we compared three ozone indicators over Europe in our LOTOS-EUROS simulations for the current land use with those for our scenario (Fig. 3). As described in the Methods, we calculated the mean of the daily ozone maxima (Fig. 3a), the AOT40f (Fig. 3b) and the SOMO35 (Fig. 3c), each based on the simulation period April 1st-October 1st, 2006. Each of these ozone indicators are projected to increase substantially (Fig. 3, middle and right panels): the daily ozone maxima increase by up to $6 \%$ (with a mean of $1.6 \%$ over the entire simulated domain), the AOT40f increases by up to $40 \%$ (spatial mean of $11.2 \%$ ) and the SOMO35 increases by up to $25 \%$ (spatial mean of $7.3 \%$ ). We found the strongest (relative) increases in the United Kingdom, the Netherlands, Germany, Italy and Ukraine.

In order to get an impression of how the temporal profiles for local ozone concentrations are affected by new poplar plantations, we studied the model projections as a function of time for the grid points containing Amsterdam in the Netherlands (Fig. 4a) and Milan in Italy (Fig. 4b) for the period July 1st-July 17th, 2006. The temporal profiles show that the strongest effect of our scenario is on the ozone maxima in the afternoons (in these examples by up to $10 \mu \mathrm{g} \mathrm{m}^{-3}$ ), and that the impact is less pronounced at other time points of the day. Moreover, the daily maxima during episodes with high ozone concentrations are much more increased than those at days with low ozone concentrations. These observations explain why especially the ozone indicators AOT40f and SOMO35 are strongly affected by new poplar plantations (Fig. 3b and c): these indicators are sensitive to high ozone concentrations.

\subsection{Required reduction in $\mathrm{NO}_{x}$ emissions to compensate for impact of poplar plantations}

Although the effect of the new poplar plantations on ozone air pollution in our LOTOS-EUROS simulations is apparent, they may appear to be relatively limited. However, changes of such a size are of the same order as observed ozone trends from 1990 to 2005 in 
(a)
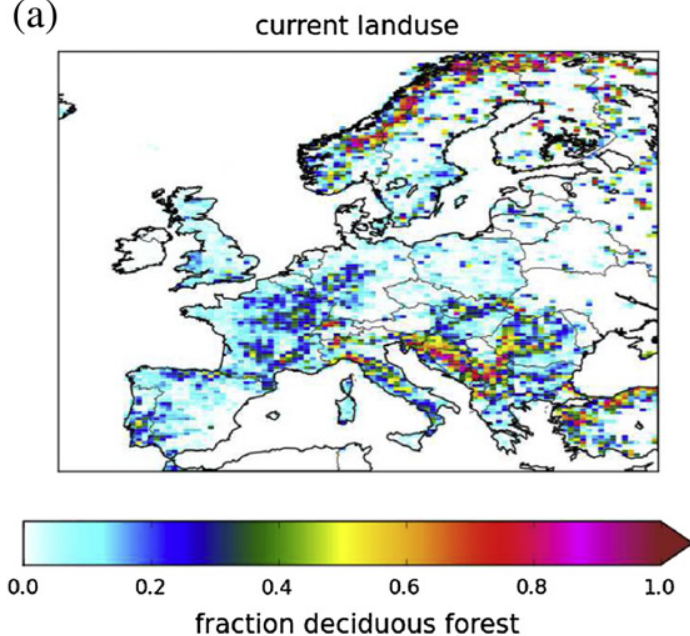

(c)
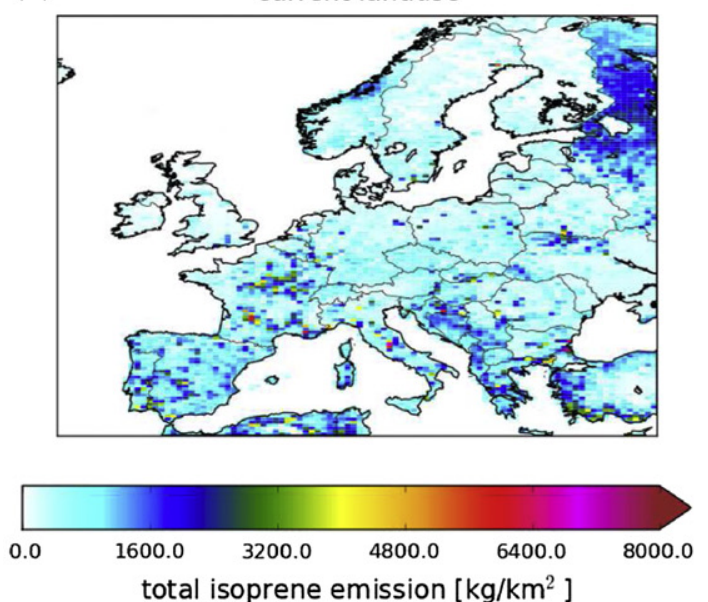

(b)
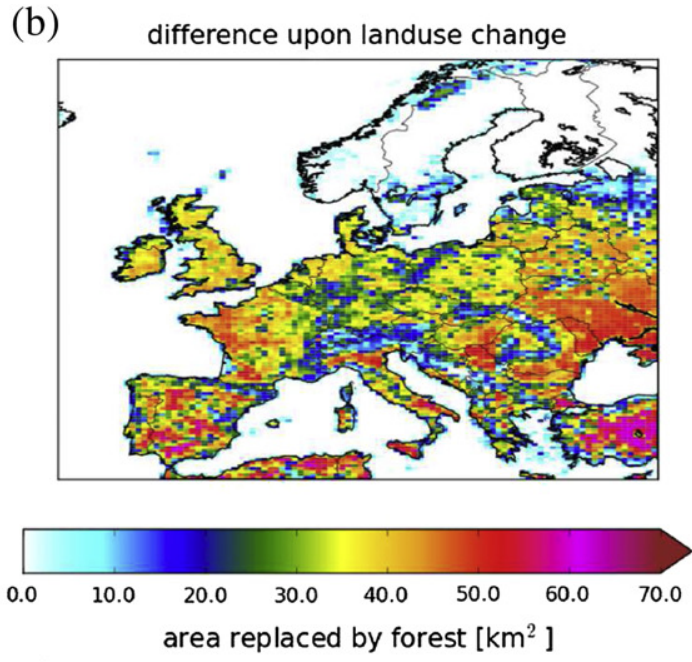

(d)
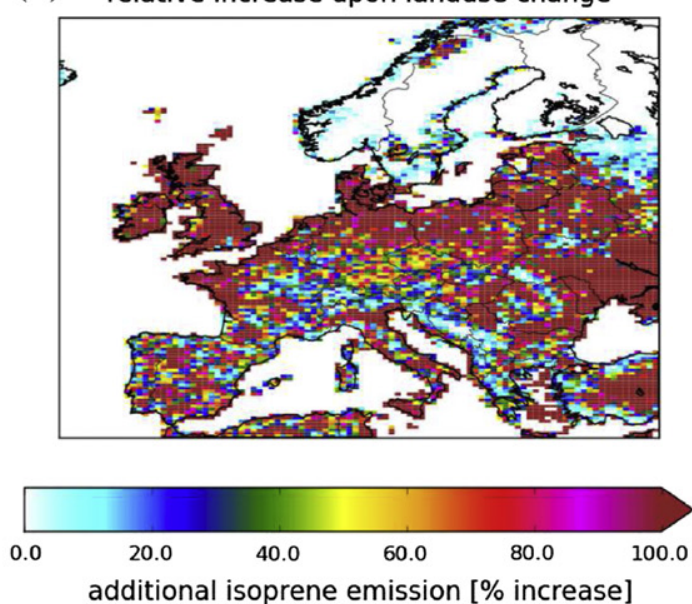

(e)

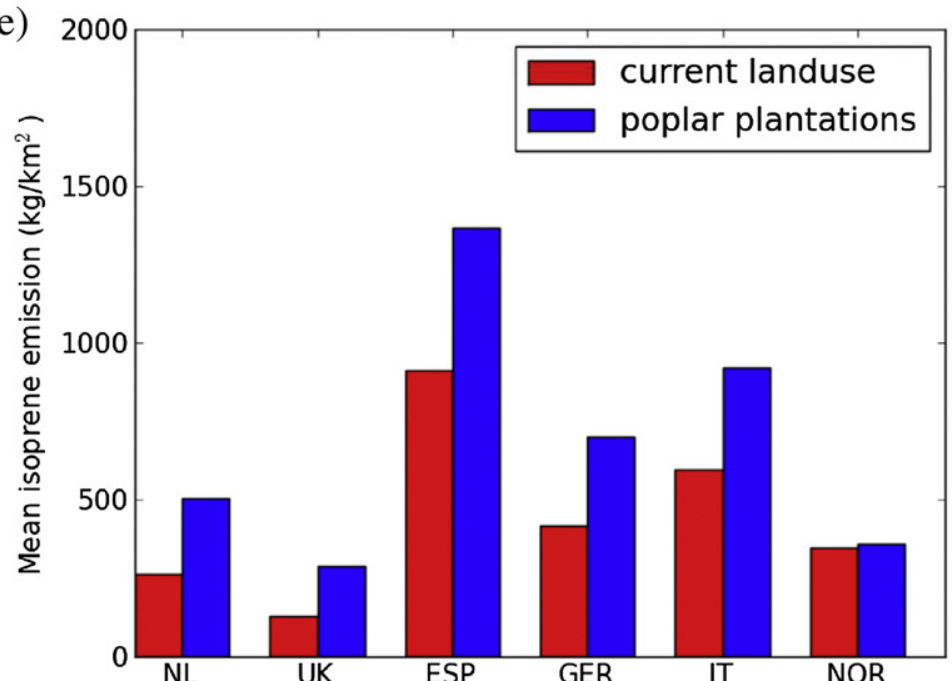

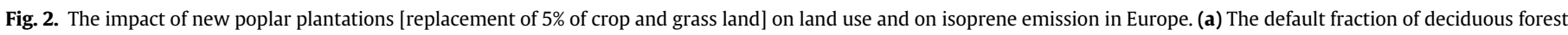

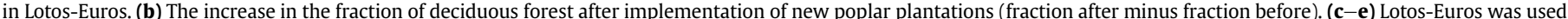

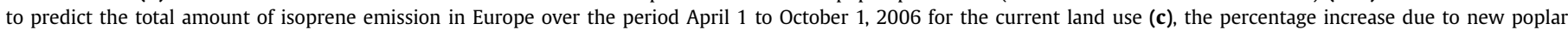

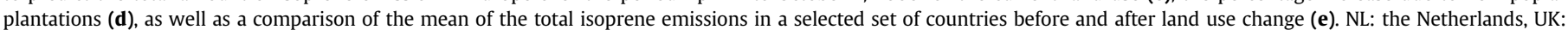
United Kingdom, ESP: Spain, GER: Germany, IT: Italy, NOR: Norway. 
(a)
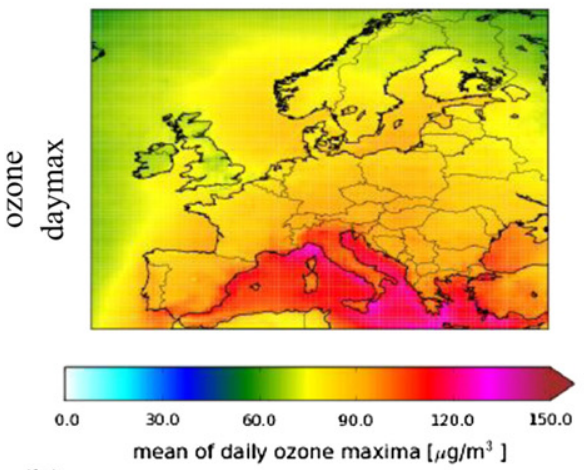

(b)
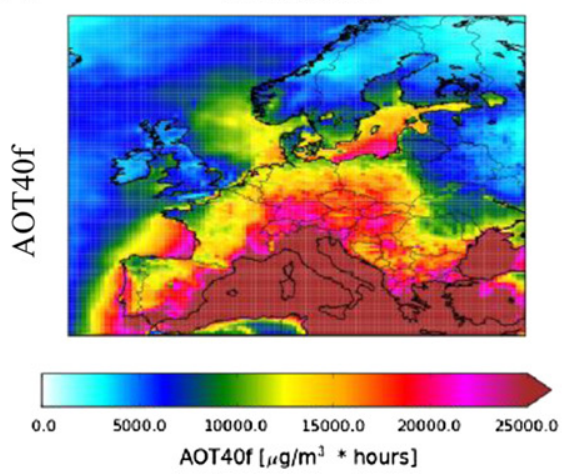

(c)
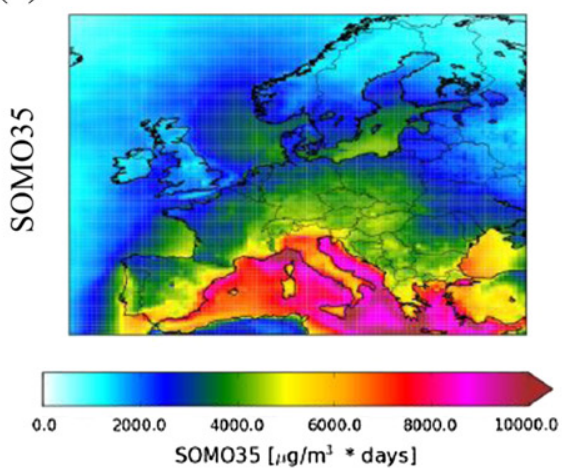

difference upon landuse change
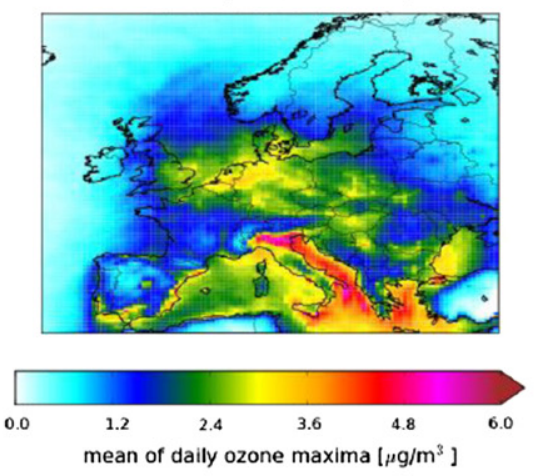

difference upon landuse change
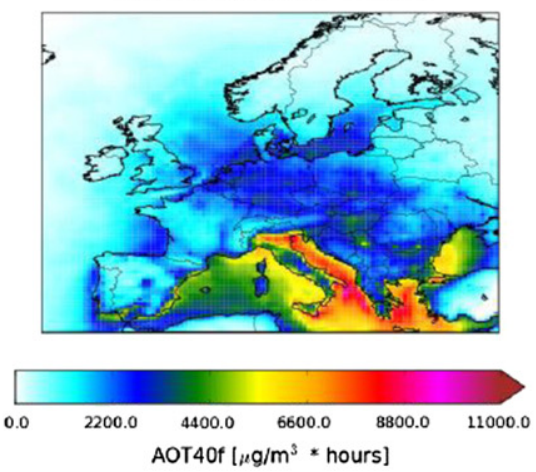

difference upon landuse change
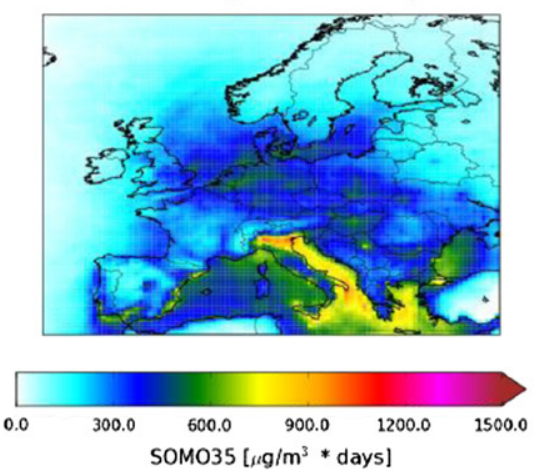

relative increase upon landuse change
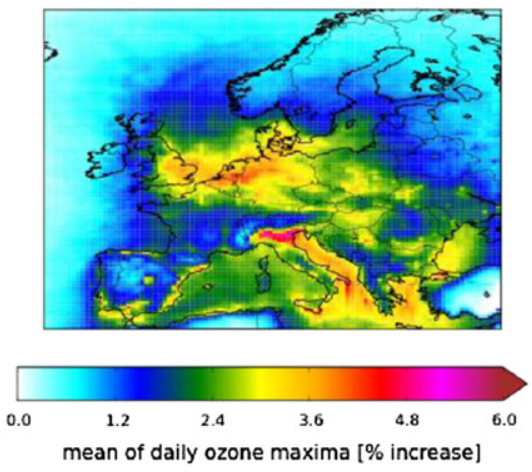

relative increase upon landuse change
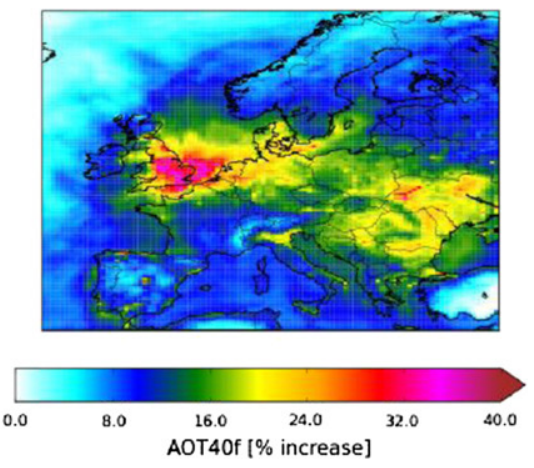

relative increase upon landuse change
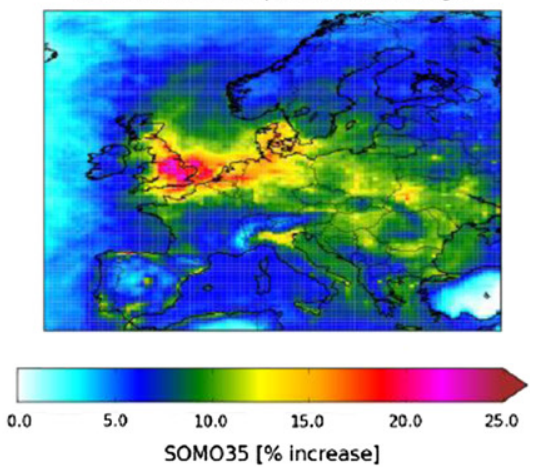

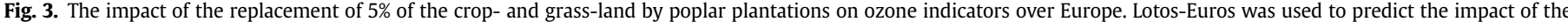

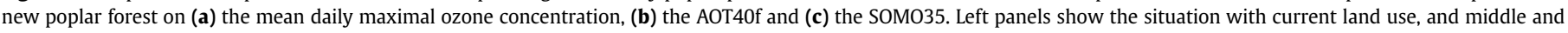
right panels respectively show the expected absolute and relative increase in the ozone indicators due to new poplar forest.

Europe (Solberg et al., 2009). To put our results further into perspective, we asked whether a substantial reduction in other emissions would be required to neutralize the effect of the land use modification. We focused on $\mathrm{NO}_{x}$ emission reductions because the relative impact of new poplar plantations is strongest in regions with high $\mathrm{NO}_{x}$ emissions such as the Netherlands and the UK (Fig. 3). Thus, LOTOS-EUROS was used to simulate the impact of up to $50 \% \mathrm{NO}_{x}$ emission reductions on top of the scenario with new poplar plantations. The simulation results for the entire simulated domain demonstrated that for each of the ozone indicators studied (mean of daily ozone maxima, AOT40f, and SOMO35) a reduction in $\mathrm{NO}_{x}$ emissions of $15-20 \%$ was able to compensate for the increase in isoprene emissions by new poplar plantations (Fig. 5a-c).

A more detailed study of the required $\mathrm{NO}_{x}$ emission reductions from the viewpoint of individual countries gave very similar quantitative results (Fig. 5d). However, for countries in Northwestern Europe such as the United Kingdom and Germany an even higher reduction in $\mathrm{NO}_{x}$ emissions of up to $50 \%$ was needed to neutralize the impact of new poplar plantations. This is because the ozone concentrations in these high- $\mathrm{NO}_{x}$ regions tend to be limited by VOCs rather than by $\mathrm{NO}_{x}$. Thus, a small decrease in $\mathrm{NO}_{x}$ emissions has a limited effect on ozone levels in Northwestern Europe. Together, our simulations with decreased $\mathrm{NO}_{x}$ emissions show that a substantial investment in such emission reductions would be needed to compensate for the effect of new poplar plantations on ozone air pollution.

\section{Discussion and conclusions}

We have studied a scenario where biomass plantations are used on a large scale for bio-based energy production within Europe. We found that for our scenario of replacing only $5 \%$ of crop- and grassland by poplar plantations, a large increase in isoprene emissions is expected (45\% increase for the entire simulated European domain). 
(a)

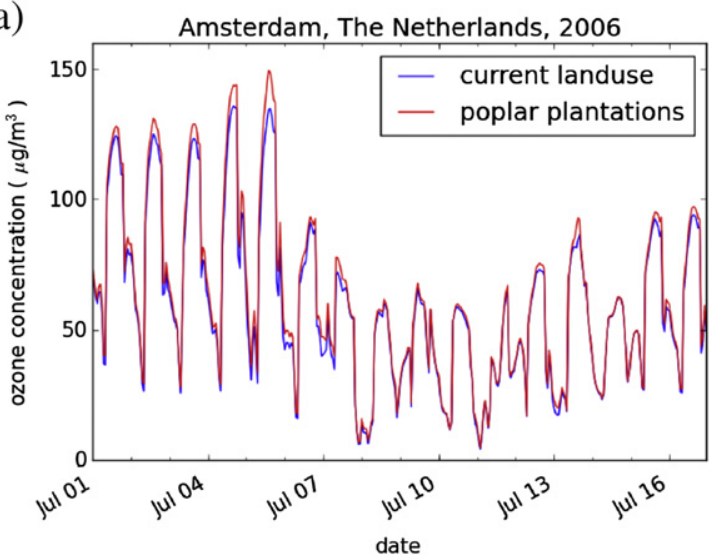

(b)

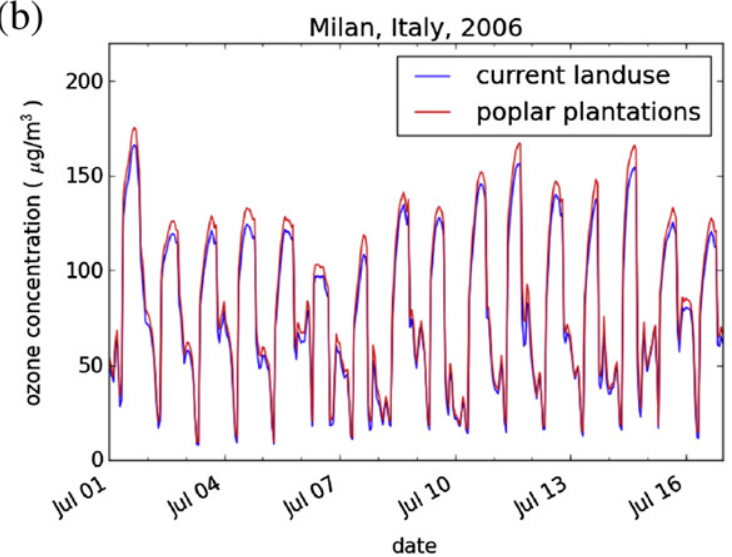

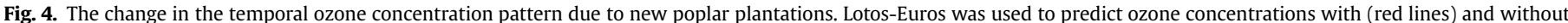

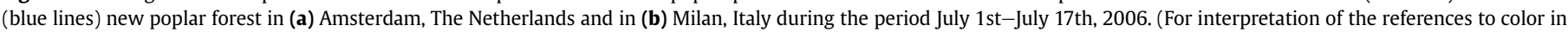
this figure legend, the reader is referred to the web version of this article.)

Because ozone is a rather insensitive component due to non-linear effects in the chemical reactions involved in ozone production, the effect of biomass production on ozone air pollution is more limited than the effect on isoprene emissions (e.g., an up to $6 \%$ increase for ozone daily maxima). Still, the additional pollution cannot be neglected because especially the daily ozone peaks are affected, i.e., when the damage to humans, animals and vegetation is highest. Moreover, we showed that the investment in for example $\mathrm{NO}_{x}$ emission reductions needed to neutralize the effect of the increased isoprene emissions is substantial: on average a $15-20 \% \mathrm{NO}_{x}$ reduction would be required, but for countries in Northwestern Europe this percentage is even higher. Between 1990 and 2005, (a)

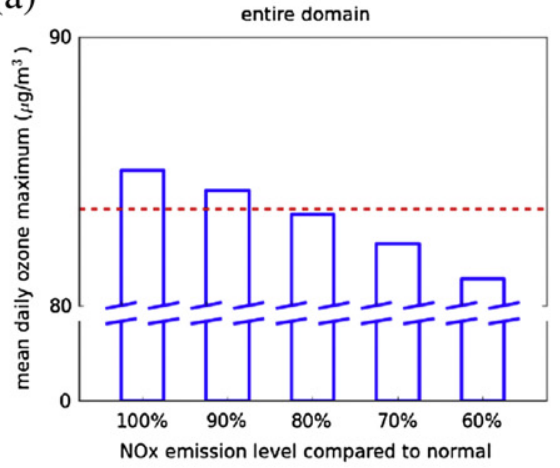

(b)

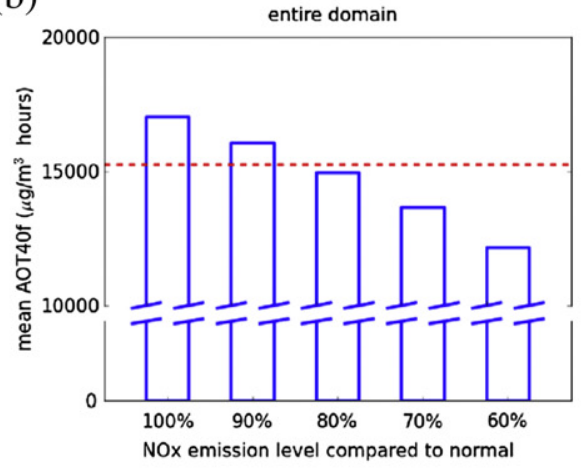

(c)

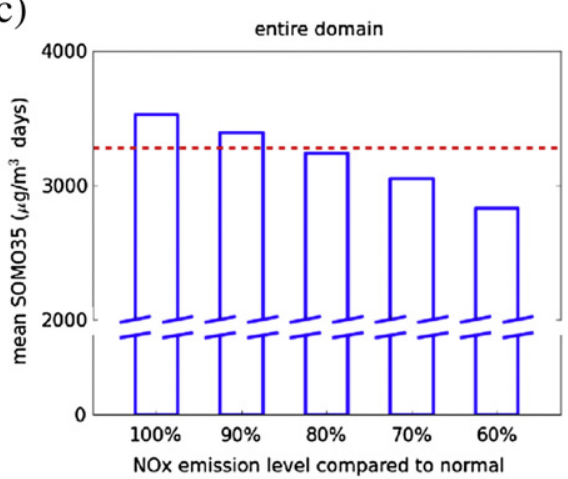

(d)
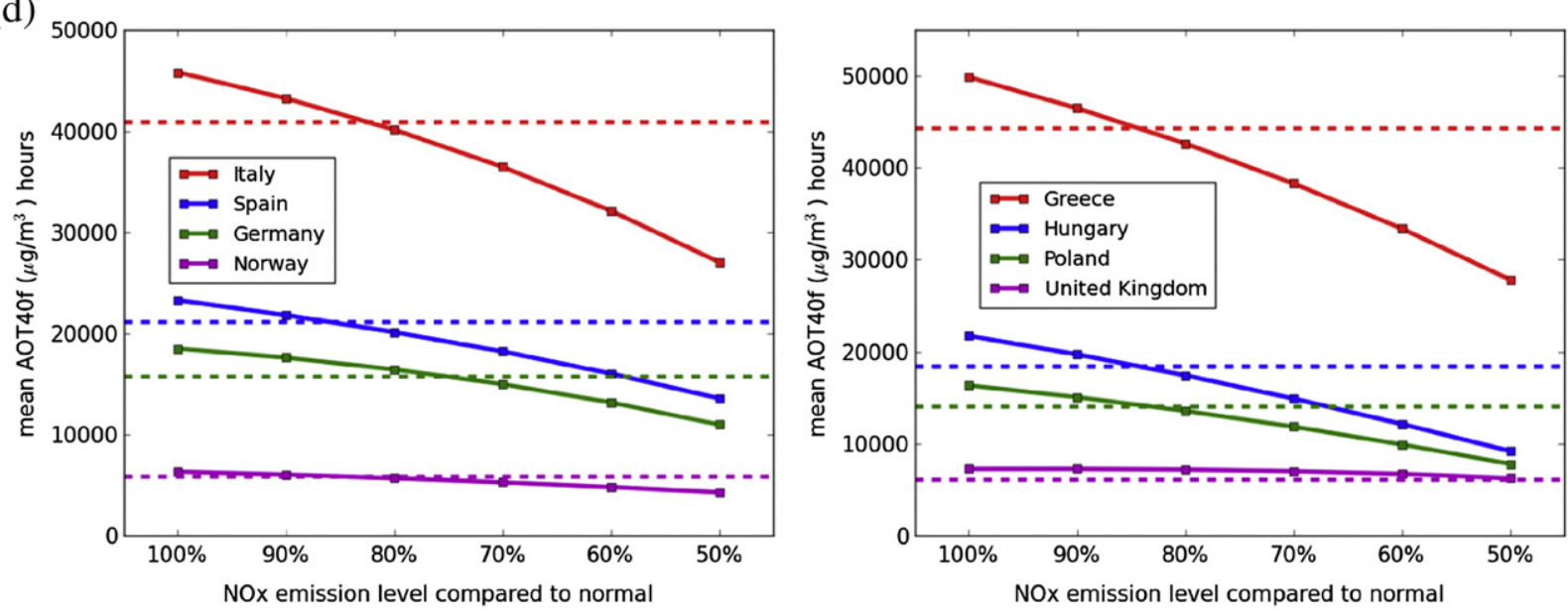

Fig. 5. A substantial reduction in anthropogenic $\mathrm{NO}_{x}$ emissions is required to compensate for ozone pollution in Europe due to new poplar plantations. Lotos-Euros was used to predict the impact of reduced $\mathrm{NO}_{x}$ emissions on the mean daily maximal ozone concentration (a), the mean AOT40f (b) and the mean SOMO35 (c) over the entire simulated domain, and on the mean AOT40f within a selected set of European countries (d). Each of the ozone indicators is calculated over the period April 1st to October 1st, 2006, and subsequently averaged over the entire simulated domain. Blue bars in $(\mathbf{a}-\mathbf{c})$ and solid lines in (d) represent results for the hypothetical future biomass production at various $\mathrm{NO}_{x}$ emission levels, whereas the dashed lines in (a-d) represents results for the current land use at a $100 \% \mathrm{NO}_{x}$ emission level. (For interpretation of the references to color in this figure legend, the reader is referred to the web version of this article.) 
annual $\mathrm{NO}_{x}$ emissions in Europe have decreased by $32 \%$ from $\sim 25 \mathrm{Tg}$ to $\sim 17 \mathrm{Tg}$, with the strongest decrease (20\%) occurring in the first half of the 1990s (Vestreng et al., 2009). Thus, when put in the perspective of $\mathrm{NO}_{x}$ emission reductions by another $15-20 \%$, the effect of new poplar plantations can be termed large. Note that we have isolated the impact of a land use change, and that a full assessment of future ozone levels across Europe should also encompass the impact of a shift to biofuels as well as emission developments in other sectors.

In previous work on the effect of biomass plantations in Europe (Ashworth et al., 2011; Lathière et al., 2006) slightly different scenarios were studied. In one extreme scenario the effect of substituting all agricultural areas in Europe by deciduous trees on isoprene emissions was investigated (Lathière et al., 2006). Isoprene emissions were more than doubled (from $15 \mathrm{Tg}^{-1}$ to $33 \mathrm{Tg} \mathrm{y}^{-1}$ ), which seems a small change compared to the mean increase in isoprene emissions of $45 \%$ we found for a land use change of only $5 \%$ rather than $100 \%$ of agricultural land. The scenarios studied by Ashworth et al. (2011), i.e., replacing up to 30\% (70 $\mathrm{MHa}$ ) of the crop- and grass-land by biomass plantations, were also more extreme than ours, yet changes of $15-30 \%$ are considered feasible (Fischer et al., 2010). This scenario resulted in an increase of annual isoprene emissions of only about $15 \%$, i.e., from $23 \mathrm{Tg} \mathrm{y}^{-1}$ to $26 \mathrm{Tg} \mathrm{y}^{-1}$ for Europe. Note that in both studies the estimates for present-day isoprene emissions were high compared to most other estimates including ours of $5 \mathrm{Tg}^{-1}$ (for an overview see Karl et al. (2009). This highlights the large uncertainties involved in inventories of biogenic emissions. Factors that are likely to have a role in the high estimates by Lathière et al. (2006) and Ashworth et al. (2011) include their more eastward extension of the simulated domains $\left(50^{\circ} \mathrm{E}\right.$ versus $35^{\circ} \mathrm{E}$ in our case) and grasses and crops being considered as significant isoprene emitters $\left(16 \mu \mathrm{g} \mathrm{g}_{\mathrm{DM}}^{-1} \mathrm{~h}^{-1}\right.$ and $5 \mu \mathrm{g} \mathrm{g}_{\mathrm{DM}}^{-1} \mathrm{~h}^{-1}$, respectively; compare to Table 1 ). Moreover, Ashworth et al. (2011) used a mechanistic, photosynthesis-based scheme to calculate emissions (developed by Pacifico et al. (2011) rather than the commonly used empirical relationships proposed by Guenther et al. (1993) and Guenther (1995)). The already high isoprene emissions for the baseline case might in part explain the limited effect of biomass plantations on isoprene emissions in the studies by Lathière et al. (2006) and Ashworth et al. (2011). However, probably the most important factor explaining this limited effect is the difference between the isoprene emission factors of grasses/crops (lower in our case than in the other studies) and those of the replacing forest species (higher in our case than in the other studies). Lathière et al. (2006) did not study the consequences of the increased isoprene emissions on ozone air pollution. The increase in mean ozone concentrations of up to 3\% during July projected by Ashworth et al. (2011) is roughly consistent with the changes projected by our simulations (when taking the different isoprene emissions into account).

All model input data and process descriptions are associated with uncertainties. As a consequence, it is difficult to provide a quantification of the uncertainty of a complete simulation. Instead, we provide a qualitative assessment of the most important parameters leading to uncertainty of our results. Uncertainties concerning land use classification are anticipated to be low and random. Tree species distributions and their emission factors are much more uncertain and may cause regional uncertainties. In Table 3 we compare country specific isoprene emission totals to those obtained by Simpson et al. (1999). This analysis shows that many countries have comparable emission estimates in both studies. The largest absolute differences are found for Spain, Italy and France (in either direction). Comparing the sum overall countries covered by both studies shows 17\% lower emissions for Simpson et al. (1999). Similar to our results, Steinbrecher et al.
Table 3

Comparison of annual total Isoprene emissions $\left(\mathrm{Gg} \mathrm{yr}^{-1}\right)$ as calculated for the base case and the scenario incorporating new poplar plantations. Furthermore, a comparison to emission totals derived by Simpson et al. (1999) (S99) is given.

\begin{tabular}{|c|c|c|c|c|c|c|c|}
\hline Country & Base case & Poplar & S99 & Country & Base case & Poplar & S99 \\
\hline Albania & 35 & 45 & 40 & Ireland & 11 & 25 & 3 \\
\hline Austria & 36 & 51 & 29 & Italy & 257 & 398 & 44 \\
\hline Belgium & 16 & 24 & 11 & Lithuania & 19 & 43 & 0 \\
\hline Bulgaria & 107 & 151 & 61 & Luxembourg & 3 & 4 & 1 \\
\hline $\begin{array}{l}\text { Bosnia and } \\
\text { Herzegowina }\end{array}$ & 66 & 76 & 51 & Latvia & 25 & 41 & 12 \\
\hline Belarus & 78 & 154 & & Moldova & 10 & 30 & \\
\hline Switzerland & 22 & 26 & 5 & Macedonia & 20 & 29 & 21 \\
\hline Cyprus & 6 & 11 & & Malta & 0 & 0 & \\
\hline Czech Rep. & 43 & 66 & 15 & Netherlands & 13 & 25 & 10 \\
\hline Germany & 156 & 262 & 113 & Norway & 127 & 131 & 33 \\
\hline Denmark & 11 & 24 & 5 & Poland & 139 & 246 & 72 \\
\hline Spain & 521 & 783 & 294 & Portugal & 105 & 154 & 67 \\
\hline Estonia & 14 & 26 & 1 & Romania & 125 & 212 & 119 \\
\hline Finland & 63 & 64 & 39 & Slovakia & 29 & 42 & 43 \\
\hline France & 507 & 708 & 873 & Slovenia & 16 & 19 & 13 \\
\hline U.K. & 48 & 106 & 58 & Sweden & 129 & 143 & 120 \\
\hline Greece & 191 & 251 & 121 & Turkey & 398 & 589 & \\
\hline Croatia & 74 & 94 & 34 & Ukraine & 208 & 432 & 280 \\
\hline Hungary & 75 & 121 & 86 & Yugoslavia & 90 & 126 & 79 \\
\hline
\end{tabular}

(2009) compared different emission modules including different land use data, emission factors and process descriptions and arrived at a $13 \%$ difference on the European isoprene emissions, though differences for individual grid cells could be a factor two. Considering the large uncertainty in isoprene emission factors amongst species, it seems that for our results especially the emission factors of poplars and grasses dominate the uncertainty in isoprene emissions.

An increase in forest land cover causes a more effective dry deposition of ozone due to enhanced roughness. Sensitivity simulations show that this indirect effect of poplar plantations (i.e., through increased dry deposition) on ozone concentrations is more than one order of magnitude smaller than the direct impact on the isoprene emission change (not shown). Note that uncertainties in dry deposition process descriptions itself are large (Dore et al., 2012; Geels et al., 2012), especially for high temperatures and dry conditions, which may have contribute to underestimated ozone peak values in both simulations. Other process uncertainties come from the representation of chemistry. Comparison of several chemistry mechanisms reveals that the CBM-IV mechanism in general yields an ozone production per unit isoprene that is on the low side of the range (Emmerson and Evans, 2009). Therefore, the (absolute) increase in ozone levels because of increased isoprene emissions found in our current study is expected to be a rather low estimate. This conclusion is substantiated by the systematic underestimation of ozone levels and indicators by LOTOS-EUROS. In LOTOS-EUROS, isoprene nitrates are not explicitly included but their formation is accounted for as a simple loss term for the $\mathrm{NO}_{3}$ radical. However, isoprene nitrates may represent an important $\mathrm{NO}_{x}$ reservoir in regions with high $\mathrm{VOC}$ to $\mathrm{NO}_{x}$ ratios such as remote tropical areas (Beaver et al., 2012). These conditions are not likely to be present in Europe. Nevertheless, future research should describe the ozone cascade in more detail, including a more detailed chemical scheme for the degradation of biogenic as well as anthropogenic VOCs.

Other studies on the impact of land use changes on ozone pollution (in non-European regions) have emphasized the importance of $\mathrm{NO}_{x}$ concentrations. The effect of increased isoprene emissions on ozone concentrations depends on whether the region of interest is ' $\mathrm{NO}_{x}$-sensitive' or 'VOC-sensitive' (Sillman, 1999). In environments with a lot of $\mathrm{NO}_{x}$ pollution (low $\mathrm{VOC}: \mathrm{NO}_{x}$ ratios), 
increased isoprene emissions tend to lead to higher ozone levels. However, in relatively clean environments with low $\mathrm{NO}_{x}$ concentrations increased isoprene emissions may lead to reduced ozone concentrations. Indeed, Europe is in general a region with high $\mathrm{NO}_{x}$ concentrations, hence the general increase in ozone pollution due to biomass plantations we found. In other regions in the world $\mathrm{NO}_{x}$ levels are frequently lower. A number of studies on the impact of land use change has been performed for South-East Asia because of the fast local expansion of oil palm plantations in the past decades. Experimental measurements demonstrated that isoprene emissions from oil palm plantations in South-East Asia are larger than those from nearby tropical rainforests (MacKenzie et al., 2011). It was projected that further extensions of such plantations in SouthEast Asia will greatly increase surface ozone levels when the additional $\mathrm{NO}_{x}$ emissions for fertilization, transport and processing in the oil palm industry are taken into account (Pyle et al., 2011; Ashworth et al., 2011). Thus, nitrogen management in such tropical regions is essential to prevent ozone air pollution (Hewitt et al., 2009). Wiedinmyer et al. (2006) demonstrated a similar important role of $\mathrm{NO}_{x}$ upon planting of new oil palm, Eucalyptus and poplar forests in the Amazon and the Western United States. Their simulations projected that the increased isoprene emissions due to such plantations would lead to decreased ozone concentrations in the low- $\mathrm{NO}_{x}$ regions (Amazon and Northwestern US) and to increased ozone concentrations in high- $\mathrm{NO}_{x}$ regions (Southwestern US). Hence, future studies could also include the impact of other emissions directly associated with biomass plantations such as combustion and transport.

Because we studied a scenario that was careful in terms of the amount of land modified into biomass plantations over Europe, ozone levels may be much more strongly affected in the future than in our conservative scenario. Most of the land expected to become available for biomass production is located in Eastern Europe, where for some countries up to half of the agricultural lands could in the future be sacrificed for biomass forests (Fischer et al., 2010). Hence, especially in Eastern Europe ozone air pollution might become severe, although a quantitative estimate of the effects would need to be studied in more detailed scenarios. These scenarios could also address the exacerbating impact of global warming, which is likely to be important (Jacob and Winner, 2009). Nevertheless, the current simulations demonstrate that even a relatively small modification in land use notably increases ozone air pollution, and that neutralizing this increase by decreasing other emissions would require quite an investment. One way to decrease the effect of future land use modifications on air pollution, is to use where possible species that emit less isoprene yet are suitable for fast biomass production. Thus, willow and Eucalyptus forests are in this respect a better choice than poplar plantations (see Table 1; note that a ' $19 \%$ willow' scenario would give about the same ozone increase as our ' $5 \%$ poplar' scenario). It may also be possible to develop transgenic non-isoprene emitting species, as was for example achieved for poplars (Behnke et al., 2007). However, such species could have problems in dealing with heat stress (Behnke et al., 2007).

Large-scale transitions toward renewable energies are at first sight expected to be purely beneficial for the environment because they lead to a reduction of for instance carbon dioxide production. However, our study shows that the impact of switching to renewables can also be in part detrimental, and that the effect on other air pollutants such as ozone should also be considered. Thus, before large-scale transitions toward renewables are effectuated, expected air quality changes should be carefully studied in all their aspects, including a shift to combustion of biofuels as well as the associated land use change. Global as well as regional CTMs are indispensable in the study of scenarios representing transitions toward renewable energies.

\section{Acknowledgments}

This study was funded by the 7th Framework Programme of the European Commission EnerGEO (grant 226364). For more information see http://www.energeo-project.eu.

\section{References}

Adams, R.M., Crocker, T.D., Thanvaibulchai, N., 1982. An economic assessment of air pollution damages to selected annual crops in southern California. Journal of Environmental Economics and Management 9, 42-58.

Adelman, Z.E., 1999. A Reevaluation of the Carbon Bond-IV Photochemical Mechanism. M.Sc. thesis, Department of Environmental Sciences and Engineering, School of Public Health, University of North Carolina, USA.

Ashworth, K., Folberth, G., Hewitt, C.N., Wild, O., 2011. Impacts of near-future cultivation of biofuel feedstocks on atmospheric composition and local air quality. Atmospheric Chemistry and Physics 11, 24857-24939.

Barbu, A.L., Segers, A.J., Schaap, M., Heemink, A.W., Builtjes, P.J.H., 2009. A multicomponent data assimilation experiment directed to sulphur dioxide and sulphate over Europe. Atmospheric Environment 43, 1622-1631.

Beaver, M.R., St. Clair, J.M., Paulot, F., Spencer, K.M., Crounse, J.D., LaFranchi, B.W., Min, K.E., Pusede, S.E., Wooldridge, P.J., Schade, G.W., Park, C., Cohen, R.C., Wennberg, P.O., 2012. Importance of biogenic precursors to the budget of organic nitrates: observations of multifunctional organic nitrates by CIMS and TD-LIF during BEARPEX 2009. Atmospheric Chemistry and Physics 12, 5773-5785.

Behnke, K., Ehlting, B., Teuber, M., Bauerfeind, M., Louis, S., Hänsch, R., Polle, A., Bohlmann, J., Schnitzler, J., 2007. Transgenic, non-isoprene emitting poplars don't like it hot. Plant Journal 51, 485-499.

Bell, M.L., McDermott, A., Zeger, S.L., Samet, J.M., Dominici, F., 2004. Ozone and short-term mortality in 95 US urban communities, 1987-2000. Journal of the American Medical Association 292 (19), 2372-2378. http://dx.doi.org/10.1001/ jama.292.19.2372.

BMU (Bundesministeriums für Umwelt, Naturschutz und Reaktorsicherheit), 2012. Renewable Energy Sources in Figures - National and International Development. Brochure from the Federal Ministry for the Environment, Nature Conservation and Nuclear Safety in Germany. Available at: http://erneuerbareenergien.de/inhalt/5996/2720/.

Builtjes, P.J.H., van Loon, M., Schaap, M., Teeuwisse, S., Visschedijnk, A.J.H., Bloos, J.P., 2003. Project on the Modelling and Verification of Ozone Reduction Strategies: Contribution of TNO-MEP.

Chen, J., Avise, J., Guenther, A., Wiedinmyer, C., Salathe, E., Jackson, R.B., Lamb, B., 2009. Future land use and land cover influences on regional biogenic emissions and air quality in the united states. Atmospheric Environment 43, 5771-5780.

Curci, G., Beekmann, M., Vautard, R., Smiatek, G., Steinbrecher, R., Theloke, J., Friedrich, R., 2009. Modelling study of the impact of isoprene and terpene biogenic emissions on European ozone levels. Atmospheric Environment 43, 1444-1455.

Curier, R.L., Timmermans, R., Calabretta-Jongen, S., Eskes, H., Segers, A., Swart, D. Schaap, M., 2012. Improving ozone forecasts over Europe by synergistic use of the LOTOS-EUROS chemical transport model and in-situ measurements. Atmospheric Environment 60, 217-226.

Cuvelier, C., Thunis, P., Vautard, R., Amann, M., Bessagnet, B., Bedogni, M. Berkowicz, R., Brandt, J., Brocheton, F., Builtjes, P., Coppalle, A., Denby, B., Douros, G., Graf, A., Hellmuth, O., Honoré, C., Hodzic, A., Jonson, J., Kerschbaumer, A., de Leeuw, F., Minguzzi, E., Moussiopoulos, N., Pertot, C., Pirovano, G., Rouil, L., Schaap, M., Stern, R., Tarrason, L., Vignati, E., Volta, M., White, L., Wind, P., Zuber, A., 2007. CityDelta: a model intercomparison study to explore the impact of emission reductions in European cities in 2010. Atmospheric Environment 41, 189-207.

Denier van der Gon, H.A.C., Visschedijk, A., van den Brugh, H., Dröge, R., 2010. F\&E Vorhaben: "Strategien Zur Verminderung Der Feinstaubbelastung"-PAREST: a High Resolution European Emission Data Base for the Year 2005. TNO-Report, TNO-034-UT-2010-01895_RPT-ML, Utrecht.

Dentener, F., Stevenson, D., Cofala, J., Mechler, R., Amann, M., Bergamaschi, P., Raes, F., Derwent, R., 2005. The impact of air pollutant and methane emission controls on tropospheric ozone and radiative forcing: CTM calculations for the period 1990-2030. Atmospheric Chemistry and Physics 5, 1731-1755.

Dore, A.J., Kryza, M., Hall, J.R., Hallsworth, S., Keller, V.J.D., Vieno, M., Sutton, M.A., 2012. The influence of model grid resolution on estimation of national scale nitrogen deposition and exceedance of critical loads. Biogeosciences 9, 1597-1609.

Emberson, L.D., Ashmore, M.R., Simpson, D., Tuovinen, J., Cambridge, H.M., 2000a. Towards a Model of Ozone Deposition and Stomatal Uptake Over Europe. EMEP/ MSC-W 6/2000. Norwegian Meteorological Institute, Oslo, Norway.

Emberson, L.D., Ashmore, M.R., Simpson, D., Tuovinen, J., Cambridge, H.M., 2000b. Modelling stomatal ozone flux across Europe. Water, Air and Soil Pollution 109, 403-413.

Emery, C., Jung, J., Downey, N., Johnson, J., Jimenez, M., Yarwood, G., Morris, R., 2012. Regional and global modeling estimates of policy relevant background ozone over the United States. Atmospheric Environment 47, 206-217.

Emmerson, K.M., Evans, M.J., 2009. Comparison of tropospheric gas-phase chemistry schemes for use within global models. Atmospheric Chemistry and Physics $9,1831-1845$ 
Emmons, L.K., Walters, S., Hess, P.G., Lamarque, J., Pfister, G.G., Fillmore, D., Granier, C., Guenther, A., Kinnison, D., Laepple, T., Orlando, J., Tie, X., Tyndall, G. Wiedinmyer, C., Baughcum, S.L., Kloster, S., 2010. Description and evaluation of the model for ozone and related chemical tracers, version 4 (MOZART-4). Geoscientific Model Development 3, 43-67.

Erisman, J.W., van Pul, A., Wyers, P., 1994. Parametrization of surface-resistance for the quantification of atmospheric deposition of acidifying pollutants and ozone. Atmospheric Environment 28, 2595-2607.

Fischer, G., Prieler, S., van Velthuizen, H., Berndes, G., Faaij, A., Londo, M., de Wit, M., 2010. Biofuel production potentials in Europe: sustainable use of cultivated land and pastures, part II: land use scenarios. Biomass and Bioenergy 34, 173-187.

Flemming, J., Inness, A., Flentje, H., Huijnen, V., Moinat, P., Schultz, M.G., Stein, O., 2009. Coupling global chemistry transport models to ECMWF's integrated forecast system. Geoscientific Model Development 2, 253-265

Ganzeveld, L., Bouwman, L., Stehfest, E., Van Vuuren, D.P., Eickhout, B., Lelieveld, J., 2010. Impact of future land use and land cover changes on atmospheric chemistry-climate interactions. Journal of Geophysical Research D: Atmospheres 115.

Geels, C., Andersen, H.V., Ambelas Skjøth, C., Christensen, J.H., Ellermann, T., Løfstrøm, P., Gyldenkærne, S., Brandt, J., Hansen, K.M., Frohn, L.M., Hertel, O. 2012. Improved modelling of atmospheric ammonia over Denmark using the coupled modelling system DAMOS. Biogeosciences 9, 2625-2647.

Guenther, A., 1995. A global model of natural volatile organic compound emissions. Journal of Geophysical Research 100, 8873-8892.

Guenther, A.B., Zimmerman, P.R., Harley, P.C., Monson, R.K., Fall, R., 1993. Isoprene and monoterpene emission rate variability: model evaluations and sensitivity analysis. Journal of Geophysical Research 98D, 12609-12617.

Hass, H., Van Loon, M., Kessler, C., Matthijsen, J., Sauter, F., Stern, R., Zlatev, R., Langner, J., Fortescu, V., Schaap, M., 2003. Aerosol Modeling: Results and Intercomparison from European Regional-scale Modeling Systems, a Contribution to the EUROTRAC-2 Subproject GLOREAM. EUROTRAC Report.

Hewitt, C.N., MacKenzie, A.R., Di Carlo, P., Di Marco, C.F., Dorsey, J.R., Evans, M., Fowler, D., Gallagher, M.W., Hopkins, J.R., Jones, C.E., Langford, B., Lee, J.D. Lewis, A.C., Lim, S.F., McQuaid, J., Misztal, P., Moller, S.J., Monks, P.S., Nemitz, E., Oram, D.E., Owen, S.M., Phillips, G.J., Pugh, T.A.M., Pyle, J.A., Reeves, C.E., Ryder, J., Siong, J., Skiba, U., Stewart, D.J., 2009. Nitrogen management is essential to prevent tropical oil palm plantations from causing ground-level ozone pollution. Proceedings of the National Academy of Sciences of the United States of America 106, 18447-18451.

Hjellbrekke, A., Fjæraa, A.M., 2009. Data Report 2007, Acidifying and Eutrophying Compounds and Particulate Matter. EMEP/CCC-Report 1/2009.

Hollingsworth, A., Engelen, R.J., Textor, C., Benedetti, A., Boucher, O., Chevallier, F., Dethof, A., Elbern, H., Eskes, H., Flemming, J., Granier, C., Kaiser, J.W. Morcrette, J.-., Rayner, P., Peuch, V., Rouil, L., Schultz, M.G., Simmonsa, A.J., 2008. Toward a monitoring and forecasting system for atmospheric composition GEMS project. Journal of Atmospheric and Oceanic Technology 89, 1147-1164.

Jacob, D.J., Winner, D.A., 2009. Effect of climate change on air quality. Atmospheric Environment 43, 51-63.

Karl, M., Guenther, A., Köble, R., Leip, A., Seufert, G., 2009. A new European plantspecific emission inventory of biogenic volatile organic compounds for use in atmospheric transport models. Biogeosciences 6, 1059-1087.

Koeble, R., Seufert, G., 2001. Novel maps for forest tree species in Europe. In: Proceedings of the Conference "A Changing Atmosphere".

Krupa, S.V., Nosal, M., Legge, A.H., 1998. A numerical analysis of the combined opentop chamber data from the USA and Europe on ambient ozone and negative crop responses. Environmental Pollution 101, 157-160.

Kuenen, J., Denier van der Gon, H., Visschedijk, A., van der Brugh, H., van Gijlswijk, R., 2011. MACC European Emission Inventory for the Years 20032007. TNO report, TNO-060-UT-2011-00588, Utrecht.

Lathière, J., Hauglustaine, D.A., Friend, A.D., De Noblet-Ducoudré, N., Viovy, N., Folberth, G.A., 2006. Impact of climate variability and land use changes on global biogenic volatile organic compound emissions. Atmospheric Chemistry and Physics 6, 2129-2146.

MacKenzie, A.R., Langford, B., Pugh, T.A.M., Robinson, N., Misztal, P.K., Heard, D.E., Lee, J.D., Lewis, A.C., Jones, C.E., Hopkins, J.R., Phillips, G., Monks, P.S., Karunaharan, A., Hornsby, K.E., Nicolas-Perea, V., Coe, H., Gabey, A.M. Gallagher, M.W., Whalley, L.K., Edwards, P.M., Evans, M.J., Stone, D., Ingham, T., Commane, R., Furneaux, K.L., McQuaid, J.B., Nemitz, E., Seng, Y., Fowler, D. Pyle, J.A., Hewitt, C.N., 2011. The atmospheric chemistry of trace gases and particulate matter emitted by different land uses in Borneo. Philosophical Transactions of the Royal Society B: Biological Sciences 366, 3177-3195.

Manders, A.M.M., Schaap, M., Hoogerbrugge, R., 2009. Testing the capability of the chemistry transport model LOTOS-EUROS to forecast PM10 levels in the netherlands. Atmospheric Environment 43, 4050-4059.

Manders, A.M.M., Schaap, M., Querol, X., Albert, M.F.M.A., Vercauteren, J., Kuhlbusch, T.A.J. Hoogerbrugge, R., 2010. Sea salt concentrations across the European continent. Atmospheric Environment 44, 2434-2442.

Pacifico, F., Harrison, S.P., Jones, C.D., Arneth, A., Sitch, S., Weedon, G.P., Barkley, M.P., Palmer, P.I., Serça, D., Potosnak, M., Fu, T.-., Goldstein, A., Bai, J., Schurgers, G., 2011. Evaluation of a photosynthesis-based biogenic isoprene emission scheme in JULES and simulation of isoprene emissions under present-day climate conditions. Atmospheric Chemistry and Physics 11, 4371-4389.

Pyle, J.A., Warwick, N.J., Harris, N.R.P., Abas, M.R., Archibald, A.T., Ashfold, M.J., Ashworth, K., Barkley, M.P., Carver, G.D., Chance, K., Dorsey, J.R., Fowler, D., Gonzi, S., Gostlow, B., Hewitt, C.N., Kurosu, T.P., Lee, J.D., Langford, S.B., Mills, G.,
Moller, S., Mackenzie, A.R., Manning, A.J., Misztal, P., Nadzir, M.S.M., Nemitz, E., Newton, H.M., O’Brien, L.M., Ong, S., Oram, D., Palmer, P.I., Peng, L.K. Phang, S.M., Pike, R., Pugh, T.A.M., Rahman, N.A., Robinson, A.D., Sentian, J. Samah, A.A., Skiba, U., Ung, H.E., Yong, S.E., Young, P.J., 2011. The impact of loca surface changes in Borneo on atmospheric composition at wider spatial scales: coastal processes, land-use change and air quality. Philosophical Transactions of the Royal Society B: Biological Sciences 366, 3210-3224.

Royal Society, 2008. In: Fowler, D. (Ed.), Ground-level Ozone in the 21st Century: Future Trends, Impacts and Policy Implications. Science Policy Report $15 / 8$

Sanderson, M.G., Jones, C.D., Collins, W.J., Johnson, C.E., Derwent, R.G., 2003. Effect of climate change on isoprene emissions and surface ozone levels. Geophysical Research Letters 30. ASC 4-1-4-4.

Schaap, M., van Loon, M., ten Brink, H.M., Dentener, F.D., Builtjes, P.J.H., 2004a Secondary inorganic aerosol simulations for Europe with special attention to nitrate. Atmospheric Chemistry and Physics 4, 857-874.

Schaap, M., Denier Van Der Gon, H.A.C., Dentener, F.J., Visschedijk, A.J.H., Van Loon, M., ten Brink, H.M., Putaud, J., Guillaume, B., Liousse, C., Builtjes, P.J.H. 2004b. Anthropogenic black carbon and fine aerosol distribution over Europe. Journal of Geophysical Research D: Atmospheres 109 (D18207), 1-16.

Schaap, M., Manders, A.A.M., Hendriks, E.C.J., Cnossen, J.M., Segers, A.J.S., Denier van der Gon, H.A.C., Jozwicka, M., Sauter, F.J., Velders, G.J.M., Matthijsen, J. Builtjes, P.J.H., 2009. Regional Modelling of Particulate Matter for the Netherlands. PBL Report 500099008, Bilthoven, The Netherlands. Available at: http://www.rivm.nl/bibliotheek/rapporten/500099008.pdf.

Sillman, S., 1999. The relation between ozone, $\mathrm{NO}(\mathrm{x})$ and hydrocarbons in urban and polluted rural environments. Atmospheric Environment 33, 1821-1845.

Simpson, D., Winiwarter, W., Börjesson, G., Cinderby, S., Ferreiro, A., Guenther, A. Hewitt, C.N., Janson, R., Khalil, M.A.K., Owen, S., Pierce, T.E., Puxbaum, H. Shearer, M., Skiba, U., Steinbrecher, R., Tarrasón, L., Öquist, M.G., 1999. Inventorying emissions from nature in Europe. Journal of Geophysical Research D: Atmospheres 104, 8113-8152.

Simpson, D., Emberson, L., Ashmore, M., Tuovinen, J., 2007. A comparison of two different approaches for mapping potential ozone damage to vegetation. A model study. Environmental Pollution 146, 715-725.

Solazzo, E., Bianconi, R., Vautard, R., Appel, K.W., Moran, M.D., Hogrefe, C. Bessagnet, B., Brandt, J., Christensen, J.H., Chemel, C., Coll, I., Denier van der Gon, H., Ferreira, J., Forkel, R., Francis, X.V., Grell, G., Grossi, P., Hansen, A.B. Jericevic, A., Kraljevic, L., Miranda, A.I., Nopmongcol, U., Pirovano, G., Prank, M., Riccio, A., Sartelet, K.N., Schaap, M., Silver, J.D., Sokhi, R.S., Vira, J., Werhahn, J., Wolke, R., Yarwood, G., Zhang, J., Rao, S.T., Galmarini, S., 2012. Model evaluation and ensemble modelling of surface-level ozone in Europe and north america in the context of AQMEII. Atmospheric Environment 53, 60-74.

Solberg, S., Jonson, J.E., Horalek, J., Larssen, S., De Leeuw, F., 2009. Assessment of Ground-level Ozone in EEA Member Countries, with a Focus on Long-term Trends. EEA Technical Report No 7/2009, ISBN 978-92-9213-003-9.

Steinbrecher, R., Smiatek, G., Köble, R., Seufert, G., Theloke, J., Hauff, K., Ciccioli, P. Vautard, R., Curci, G., 2009. Intra- and inter-annual variability of VOC emissions from natural and semi-natural vegetation in Europe and neighbouring countries. Atmospheric Environment 43, 1380-1391.

Stern, R., Builtjes, P., Schaap, M., Timmermans, R, Vautard, R, Hodzic, A Memmesheimer, M., Feldmann, H., Renner, E., Wolke, R., Kerschbaumer, A. 2008. A model inter-comparison study focussing on episodes with elevated PM10 concentrations. Atmospheric Environment 42, 4567-4588.

Thrän, D., Bunzel, K., Seyfert, U., Zeller, V., Buchhorn, M., Müller, K., Matzdorf, B., Gaasch, N., Klöckner, K., Möller, I., Starick, A., Brandes, J., Günther, K., Tum, M. Zeddies, J., Schönleber, N., Gamer, W., Schweinle, J., Weimar, H., 2011. Global and Regional Spatial Distribution of Biomass Potentials - Status Quo and Options for Specification. DFBZ Report Nr. 7. Available at: http://www.dbfz.de/web/ fileadmin/user_upload/DBFZ_Reports/DBFZ_Report_7.pdf.

Thunis, P., Rouil, L., Cuvelier, C., Stern, R., Kerschbaumer, A., Bessagnet, B. Schaap, M., Builtjes, P., Tarrason, L., Douros, J., Moussiopoulos, N., Pirovano, G. Bedogni, M., 2007. Analysis of model responses to emission-reduction scenarios within the CityDelta project. Atmospheric Environment 41, 208-220.

Thunis, P., Cuvelier, C., Roberts, P., White, L., Stern, R. Kerschbaumer, A Bessagnet, B., Bergström, R., Schaap, M., 2010. EURODELTA: Evaluation of a Sectoral Approach to Integrated Assessment Modelling - Second Report. In: EUR - Scientific and Technical Research Series - 24474 EN-2010. Publications Office of the European Union, Luxembourg. ISSN 1018-5593.

Tingey, D.T., Manning, M., Grothaus, L.C., Burns, W.F., 1980. Influence of light and temperature on monoterpene emissions rates from slash pine. Plant Physiology 65, 797-801.

Van Loon, M., Vautard, R., Schaap, M., Bergström, R., Bessagnet, B., Brandt, J. Builtjes, P.J.H., Christensen, J., Cuvelier, K., Jonson, J.E., Krol, M., Langner, J., Roberts, P., Rouil, L., Stern, R., Tarrasón, L., Thunis, P., Vignati, E., White, L. Wind, P., 2007. Evaluation of long-term ozone simulations from seven regional air quality models and their ensemble. Atmospheric Environment 41, 20832097.

Van Zanten, M.C., Sauter, F.J., Wichink Kruit, R.J., Van Jaarsveld, J.A., Van Pul, W.A.J., 2010. Description of the DEPAC Module: Dry Deposition Modelling with DEPAC_GCN2010. RIVM Report 680180001/2010. Bilthoven, the Netherlands.

Vautard, R., Schaap, M., Bergström, R., Bessagnet, B., Brandt, J., Builtjes, P.J.H., Christensen, J.H., Cuvelier, C., Foltescu, V., Graff, A., Kerschbaumer, A., Krol, M., Roberts, P., Rouill, L., Stern, R., Tarrason, L., Thunis, P., Vignati, E., Wind, P., 2009. 
Skill and uncertainty of a regional air quality model ensemble. Atmospheric Environment 43, 4822-4832.

Vestreng, V., Ntziachristos, L., Semb, A., Reis, S., Isaksen, I.S.A., Tarrasón, L., 2009 Evolution of $\mathrm{NO}_{x}$ emissions in Europe with focus on road transport control measures. Atmospheric Chemistry and Physics 9, 1503-1520.

Walcek, C.J., 2000. Minor flux adjustment near mixing ratio extremes for simplified yet highly accurate monotonic calculation of tracer advection. Journal of Geophysical Research D: Atmospheres 105, 9335-9348.
Whitten, G., Hogo, H., Killus, J., 1980. The carbon bond mechanism for photochemical smog. Environmental Science and Technology 14, 14690-14700.

Wiedinmyer, C., Tie, X., Guenther, A., Neilson, R., Granier, C., 2006. Future changes in biogenic isoprene emissions: how might they affect regional and global atmospheric chemistry? Earth Interactions 10,1-19.

Wild, O., Prather, M.J., 2006. Global tropospheric ozone modeling: quantifying errors due to grid resolution. Journal of Geophysical Research 111, d11305. http:// dx.doi.org/10.1029/2005jd006605. 